\title{
Ecophysiological aspects of guava (Psidium guajava L.). A review
}

\section{Aspectos de la ecofisiología de la guayaba (Psidium guajava L.). Una revisión}
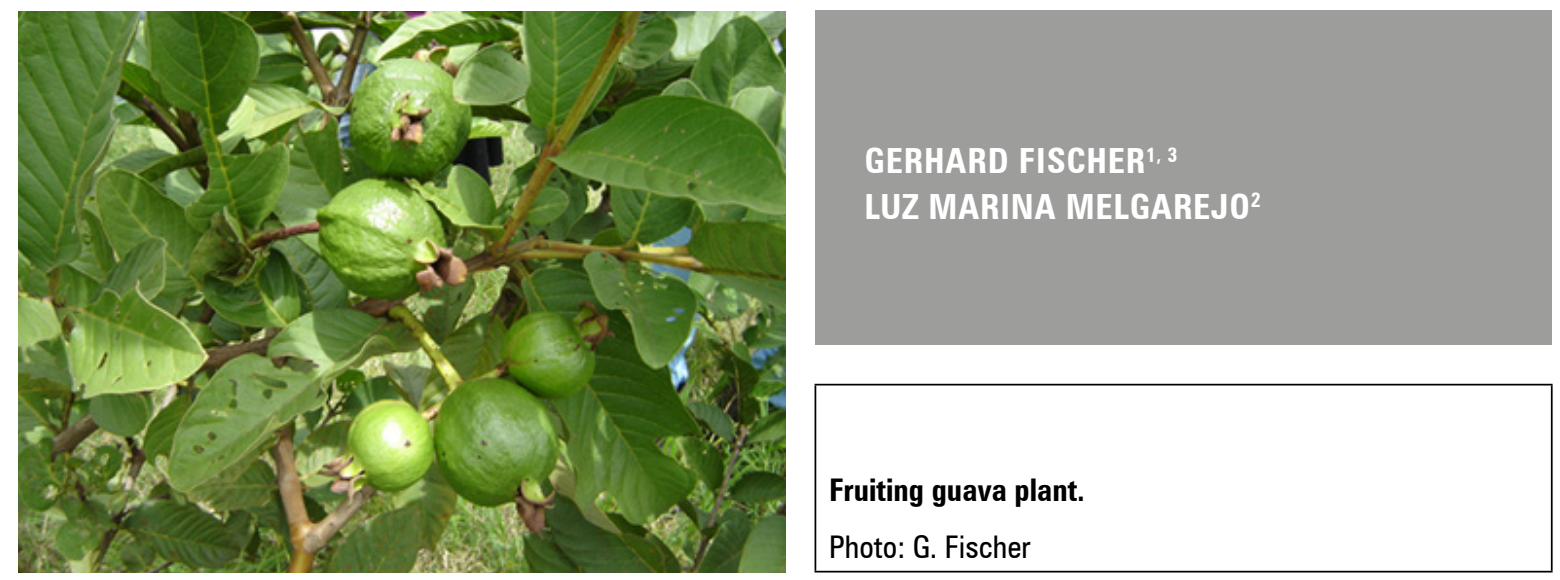

\begin{abstract}
Guava, because of its ability to grow in tropical and subtropical climates, has been introduced to some 60 low-latitude countries. It is adapted to a temperature range between 15 and $30^{\circ} \mathrm{C}$. Outside this range, the effect of lower or higher temperatures reduces fruit set, while night temperatures of 5 to $7^{\circ} \mathrm{C}$ stop growth. Additionally, low temperatures hinder production, causing flowers to fall or increasing the fruit development cycle, up to 220 days. When estimating the cardinal temperatures of development, the minimum threshold temperature was $10.9^{\circ} \mathrm{C}$, the optimum temperature was $17.3^{\circ} \mathrm{C}$, and the maximum threshold temperature was $51.2^{\circ} \mathrm{C}$. The guava tree adapts well to altitudes between 0 and 2,000 $\mathrm{m}$ a.s.l. in Colombia; however, there is a high genotype xenvironment interaction for production and quality characteristics in fruits with respect to the orchard elevation. Radiation $>2,000 \mu \mathrm{mol}$ photons $\mathrm{m}^{-2} \mathrm{~s}^{-1}$ decreased the fruit ascorbic acid content. An important ecophysiological factor in guava is water, and crops require between 1,000 to 2,000 mm year ${ }^{-1}$. It withstands waterlogging for several days, but excess precipitation and atmospheric humidity decrease fruit quality considerably. However, this tree is classified as moderately drought-tolerant to stress from water deficits, affecting flowering and fruit set. It is also moderately tolerant to salinity, depending on the variety, supporting electrical conductivities up to $1.5-1.8 \mathrm{dS} \mathrm{m} \mathrm{m}^{-1}$. Generally, guava can be cultivated in a wide range of tropical and subtropical areas, where it is preferred because of its high nutritional and medicinal contents and its aptitude for transport and handling.
\end{abstract}

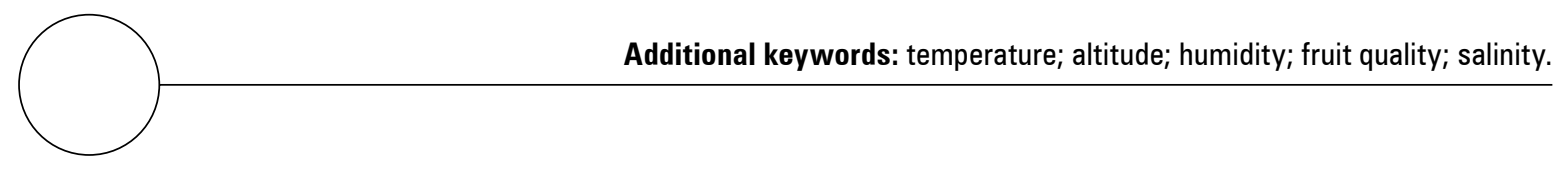

1 Independent Consulter, Emeritus Researcher of Colciencias, Bogota (Colombia). ORCID Fischer, G.: 0000-0001-8101-0507

2 Universidad Nacional de Colombia, Faculty of Sciences, Department of Biology, Bogota (Colombia). ORCID Melgarejo, L.M.: 0000-0003-3148-1911

3 Corresponding author. gerfischer@gmail.com 


\section{RESUMEN}

La guayaba, debido a su habilidad de crecer en climas tropicales y subtropicales, ha sido introducida en unos 60 países de las latitudes bajas. Se adapta a rangos de temperatura entre los 15 y $30^{\circ} \mathrm{C}$. Fuera de este rango, el efecto de temperaturas inferiores o superiores reducen, en primer lugar, el cuajamiento de los frutos, y temperaturas nocturnas de 5 a $7^{\circ} \mathrm{C}$ detienen el crecimiento. Adicionalmente, las temperaturas bajas dificultan la producción generando caída de flores o aumentando el ciclo de desarrollo del fruto hasta unos 220 días. En una estimación de las temperaturas cardinales de desarrollo se encontraron como temperatura umbral mínima $10,9^{\circ} \mathrm{C}$, temperatura óptima $17,3^{\circ} \mathrm{C}$ y temperatura umbral máxima $51,2^{\circ} \mathrm{C}$. El árbol de guayaba se adapta bien a altitudes entre 0 y 2.000 msnm en Colombia; sin embargo, existe alta interacción genotipo (variedad) ×ambiente referente a las características de producción y calidad del fruto con respecto a la elevación del sitio. Radiaciones $>2.000 \mu \mathrm{mol}$ fotones $\mathrm{m}^{-2}$ $\mathrm{s}^{-1}$ disminuyeron el contenido del ácido ascórbico en el fruto. Un factor ecofisiológico importante en la guayaba es el agua ya que los cultivos exigen entre unos 1.000 a $2.000 \mathrm{~mm}_{\text {año-1 }}$. Soportan el anegamiento de varios días; pero mucha precipitación y humedad atmosférica disminuyen la calidad del fruto considerablemente. No obstante, este árbol está clasificado como moderadamente tolerante a la sequía, el estrés por déficit hídrico afecta la floración y el cuajamiento de los frutos. Es también moderadamente tolerante a la salinidad, dependiendo de la variedad, con conductividades eléctricas hasta máximo 1,5-1,8 $\mathrm{dS} \mathrm{m}^{-1}$. En general, se puede concluir que la guayaba se puede cultivar en una amplia gama de áreas tropicales y subtropicales donde es preferida por su alto contenido nutricional y medicinal y su aptitud para el transporte y manejo.

Palabras clave adicionales: temperatura; altitud; humedad; calidad fruto; salinidad.

Received: 26-12-2020 Accepted: 17-02-2021 Published: 24-02-2021

INTRODUCTION

Because of the continuous production and supply of tropical fruits, it is possible to increase cultivation and export (Blancke, 2016). This opens a world of possibilities for improving local and global consumption with healthy foods (Viera et al., 2019). Most of the so-called "exotic fruits" are important functional foods (Moreno et al., 2014; Campos et al., 2018) and are highly valued, not only in tropical and sutropical countries but also by consumers in higher latitudes (Ramadan, 2011). This trend has greatly benefited Andean countries with increasing export volumes since the beginning of the $21^{\text {st }}$ century (Moreno-Miranda et al., 2019).

Plants require an abiotic environment to develop (Jalil and Ansari, 2020). Thus, ecophysiological studies are of utmost importance for the physical and biotic factors of the environment in terms of physiological processes in plants and interaction mechanisms that affect growth and development (Lambers et al., 2008; Fischer et al., 2016). Environmental conditions must be as close to optimal as possible for a plantation to achieve the highest crop production and quality, which are determined by the genetic potential (Pérez and Melgarejo, 2015). Most of the time, plants are grown under conditions that are not suitable for maximum development, with yields that are much lower than the maximum recorded for the species as a consequence of suboptimal environmental conditions (Raza et al., 2020). Thus, ecophysiology is closely related to environmental conditions that affect plants when conditions are not optimal for growth and development. Very small changes in abiotic factors, far from the optimum for the species, can manifest as stress for plants and have considerable effects on production (Jalil and Ansari, 2020).

Climatic factors, such as temperature, relative humidity, vapor pressure deficit, solar radiation, rain and wind, in addition to altitude, affect the ecophysiology of cultivated plants the most (Restrepo-Díaz and Sánchez-Reinoso, 2020). At low latitudes, the inner tropics lack pronounced temperature seasons, similar to temperate climate zones; consequently, the rainy and dry seasons determine to which the plant physiology reacts and adapts (Fischer and ParraCoronado, 2020).

Several abiotic factors always act simultaneously on plants, with little research (Raza et al., 2020); unlike 
studies in controlled environments that allow only one or very few factors to vary, but which do not agree with the multidimensionality (Mittler, 2006) in which all factors occur under field conditions. For this reason, more ecophysiological studies on crops are required because climate change requires the reevaluation of previous results (Restrepo-Díaz and Sánchez-Reinoso, 2020).

According to Marengo et al. (2011), climate change will not affect low areas in the tropics as much. However, the Andean areas will increase rainfall by 20 to $25 \%$. This phenomenon will consequently accelerate events such as "La Niña", causing prolonged flooding, accompanied by less solar radiation (Ramírez and Kallarackal, 2018; Sánchez-Reinoso et al., 2019; Arteaga and Burbano, 2018). Furthermore, climate change increases warming more in higher regions of the tropics than in valleys (Marengo et al., 2011).

Shukla et al. (2019) classified fruits and vegetables within the species most affected by climate change, where yield and quality tend to decrease as warming increases, mainly in tropical and subtropical areas. Also, Haokip et al. (2020) attributed the fact that fruit trees have a higher incidence of physiological disorders, problems in pollination and changes in phenology to climate change. In addition, there are many uncertainties in terms of the impacts of pests and diseases in a changing climate (Tito et al., 2018), which influence fruit quality and food security.

However, Devenish and Gianella (2012) and Raza et al. (2020) stated that atmospheric warming can increase fruit production for trees in a given site. In addition, in the Andean region, there are suitable plots at higher altitudes that have the optimum temperature of this crop (Tito et al., 2018) and optimal physiological or ecological conditions. Likewise, DaMatta et al. (2010) concluded that C3 plants, which are almost all fruit trees, could produce higher yields as the result of increased atmospheric $\mathrm{CO}_{2}$ and use less water if no other stress conditions arise because of altered regional patterns of precipitation and temperature.

Guava (Psidium guajava L.) is an evergreen tree that is native to Mesoamerica and South America (Solarte et al., 2014), possibly from Mexico to Peru (Menzel, 1985) or from Central America and southern Mexico (Blancke, 2016). Paull and Duarte (2012) and Bandera and Pérez (2015) observed the origin as "simply" being the tropical region of the Americas. Thanks to its ability to grow in tropical and subtropical climates, it has been introduced in many low-latitude countries (Singh et al., 2019). It has its highest production in India, Brazil and Mexico (Mishra et al., 2014) and on the continents South America, Asia and Australia (Singh et al., 2019). It is important for the domestic economy of more than 60 countries in the tropics (Bandera and Pérez, 2015).

The popularity of guava arises from its availability throughout the year, affordable price, high nutritional and medicinal contents, aptitude for transport and handling, and consumer preference (Methela et al., 2019).

In Colombia, Agronet (2020) reported a production of 80,814.7 t for 2018, harvested on 7,628.2 ha, mainly in the departments Boyaca (2,351.0 ha), Santander (1,790.6 ha), Tolima (841.0 ha) and Valle del Cauca (693.6 ha). 69\% is for fresh consumption, and the rest is used for making sweets, known as bocadillo (López-Santos et al., 2017).

The guava plant belongs to the myrtaceae family, known for its botanical richness and very high agroindustrial potential with 121 genera and 5,800 species of aromatic fruits, classified by Farias et al. (2020) as one of the more important commercial families globally.

Some 150 species belong to the genus Psidium (Ligarreto, 2012), and most of the cultivars are P. guajava. However, there are other species of Psidium known as $P$. cattleianum, $P$. molle, $P$. guineense, $P$. friedrichsthalianum, and P. montanum, among others (Rai and Jaiswal, 2020). P. guajava is the most cultivated in the world (Aguilera-Arango et al., 2020). Most of the species of the genus Psidium are native fruit trees from the tropical and subtropical Americas (Fischer et al., 2012).

The fruits have high levels of ascorbic acid (0.6-6.0 $\mathrm{g} \mathrm{kg}^{-1}$ edible fruit), vitamin A, calcium, phosphorus, potassium and dietary fiber (Paull and Duarte, 2012; Prado et al., 2017). In addition, they are used because of their antimicrobial, anti-inflammatory, antigenotoxic, and hepaprotective properties and for the treatment of diabetes and diarrhea (Pérez-Gutiérrez et al., 2008). Its consumption reduces triglycerides, cholesterol and blood pressure (Singh, 2007). Its flavor is bittersweet, combined with a pleasant aroma, and it is consumed fresh or processed into products such as freshly cut salads, juice, nectar, cake, puree, concentrates, jam, and gelatin, among others (Singh, 2011). 
Paull and Duarte (2012) characterized guava as a shrub, which, under good humidity conditions, can grow up to 6 to $9 \mathrm{~m}$ in height, forming trunks up to $30 \mathrm{~cm}$ or more in diameter. By pruning and training, only one stem is developed, with a height of up to 3 or $4 \mathrm{~m}$ with flexible branches and young square twigs that become rounded with age. Yadava (1996) described the guava tree as having undemanding growth with a symmetrical and pyramidal shape. It forms bisexual flowers that are $2.5-3.0 \mathrm{~cm}$ in diameter, with autogamous reproduction, considerable self-pollination (60-75\%) and 35\% cross-pollination (Fischer et al., 2012; Menzel, 1985).

The fruit contains many seeds and is botanically a berry with spherical ovoid or pyriform shapes depending on the variety, with diameters that vary between 2.5 and $10.0 \mathrm{~cm}$, skin colors between light green and yellow and white to red pulps (ParraCoronado, 2014). There are about 400 varieties in the world (Bandera and Pérez, 2015). Paull and Duarte (2012) reported that this short-cycle fruit tree begins to produce one year after planting, with maximum production at three or four years.

Because these promising crops have great potential for producers and international markets, ecophysiological impacts on quality and production characteristics (Mayorga et al., 2020) must be elucidated for the development of guava crops. Therefore, the objective of this review was to reveal climatic demands and their effects on the physiology of plants, providing the basis of processes that have taken place for the adaptation and diffusion of the species and useful information for management and breeding programs.

\section{ECOPHYSIOLOGICAL FACTORS AND THEIR INFLUENCE ON GUAVA}

There are diverse semi-wild and commercial forms, with very diverse morphological and nutritional characteristics (Solarte et al., 2014); however, plant breeding programs must develop cultivars with increasingly superior fruit qualities and resistance to abiotic and biotic stress (Thaipong and Boonprakob, 2005). The guava tree blooms and produces at different times depending on the site, climatic characteristics, soil and crop management (Bandera and Pérez, 2015), as well as the genotype and the climatic conditions, which affect the growth cycle (Salazar et al., 2006). Singh (2011) confirmed that flowering and fruiting occur continuously throughout the year in tropical and mild subtropical climates.

\section{Temperature}

According to Gómez and Rebolledo-Podleski (2006) and Salazar et al. (2006), the temperature range for the cultivation of guava is between 18 and $28^{\circ} \mathrm{C}$ and between 15 and $30^{\circ} \mathrm{C}$, respectively; while Paull and Duarte (2012) concentrated this range from 23 to $28^{\circ} \mathrm{C}$ for optimal tree performance. Temperatures lower and higher than this range reduce fruit setting, and very low night temperatures $\left(5-7^{\circ} \mathrm{C}\right)$ paralyze growth and turn leaves purple (Nakasone and Paull, 1998). If temperatures drop to $3^{\circ} \mathrm{C}$, the fruit no longer ripens (Insuasty et al., 2007). Sentelhas et al. (1996) found the lethal temperature for guava was $-4^{\circ} \mathrm{C}$ and rated it as not very tolerant to low temperatures. Paull and Duarte (2012) reported that prolonged low temperatures of $-2^{\circ} \mathrm{C}$ burn young plants.

Ferreira et al. (2019) estimated the cardinal development temperatures for guava seedlings, applying 12 different models with methodologies based on the standard deviation of the accumulated degree days of growth, calculating the base (minimum) temperature as $10.9^{\circ} \mathrm{C}$, the optimum as $17.3^{\circ} \mathrm{C}$ and the maximum as $51.2^{\circ} \mathrm{C}$. There is little information on cardinal temperatures in fruit species, which are very useful for studies on adaptation to different microclimates (Souza and Martins, 2014).

Fruits react to unfavorable conditions for their development and quality. It has been observed that, at elevated temperatures, they are more aqueous, with low sugar and ascorbic acid contents (Souza et al., 2010). In addition, under conditions of high temperatures and humidity during the development of the fruit, they become very susceptible to attacks by fruit flies (Haokip et al., 2020).

Low temperatures, such as during the winter months in the subtropics, make commercial production very difficult, increasing the time of fruit development to about 220 days (Paull and Duarte, 2012), and, if the cold season is also dry, these combined stress factors lead to natural defoliation and flowering will begin as soon as temperatures rise and rain induces a new flow of growth and fruit set (Nakasone and Paull, 1998). Haokip et al. (2020) stated that flower drop occurs in guava when low temperatures prevail during flowering. Floral opening depends on the daytime temperature (Bandera and Pérez, 2015). 
In subtropical areas, very high summer temperatures can impair the content of sugars and organic acids in fruits, which are used in respiratory processes (Solarte et al., 2014). In comparison, these authors found an increase in ascorbic acid with increasing temperature and relative humidity at tropical altitudes between 1,570 and $1,890 \mathrm{~m}$ a.s.1.

Salazar et al. (2006) measured the phenological stages of guava by also calculating the degree days of growth, adding the differences between the mean daytime temperatures and the base temperature of $12.0^{\circ} \mathrm{C}$, which was recorded when the development of the flower bud began, comparing the development of the plant between the different years and geographical sites.

\section{Radiation}

Paull and Duarte (2012) found that a greater number of hours of sunlight leads to greater growth of the branches. Also, the concentration of ascorbic acid increases with increasing light intensities; however, Solarte et al. (2014) recorded a decrease in this acid with radiation $>2,000 \mu \mathrm{mol}$ photons $\mathrm{m}^{-2} \mathrm{~s}^{-1}$.

\section{Altitude}

According to Solarte et al. (2014), the ecophysiological effect of altitude on the guava plant depends mostly on the variety but the concept of multidimensionality of Mittler (2006) must be considered because increasing altitudes decrease the temperature (about $0.6^{\circ} \mathrm{C} / 100 \mathrm{~m}$ ), the partial pressure of the air $\left(\mathrm{O}_{2}, \mathrm{CO}_{2}\right.$ and $\left.\mathrm{N}_{2}\right)$ and the relative humidity, while radiation (visible, UV and infrared), rain (from 1,300$1,500 \mathrm{~m}$ a.s.1.) and wind increase (Fischer and OrduzRodríguez, 2012).

However, since guava is a native species of the tropics, adaptation to these ranges of altitude (Tab. 1) has allowed it to be distributed in the subtropics and numerous countries of the world (Natale et al., 2008).

Solarte et al. (2014) studied the effect of three altitudes $(1,570 ; 1,720$ and $1,890 \mathrm{~m}$ a.s.l.) on fruit quality in four guava genotypes grown in a traditional semiwild system in the Department of Santander, Colombia with a bimodal rainfall regime (average rainfall/ year of $1,780 \mathrm{~mm}$ and temperature of $20^{\circ} \mathrm{C}$ ). In this study, the environmental factors that were associated with altitude and resulted in differences in fruit quality between the genotypes included the vapor pressure deficit (VPD), the maximum photosynthetic photon flux density $\left(\mathrm{PPFD}_{\max }\right)$ and the temperature difference between day and night $\left(\Delta \mathrm{T}^{\circ}\right)$. It was observed that, at low altitudes (with higher temperature and solar radiation), the fruits had a higher fresh weight and changed faster from green to yellow; while, in general, the content of organic acids increased with increasing altitude. Likewise, the higher altitude conditions promoted efficiency in the accumulation of the monosaccharides fructose and glucose, but only in two of the four genotypes. Solarte et al. (2014) stated that there was a genotypexenvironment interaction effect on all variables because not all genotypes reacted uniformly.

Musyarofah et al. (2020) evaluated 'Kristal' guavas from low (200 $\mathrm{m}$ a.s.1.) and middle (550 $\mathrm{m}$ a.s.l.) altitudes in Indonesia and found that fruits from the low elevation were heavier and bigger, with a higher vitamin E-content than in those grown in the middle altitude farm, with fruits that were crispier and not as soft as the low elevation ones.

\section{Water}

Water is essential for all reproductive phases of guava (Fischer et al., 2012). In a high Andean phenological study on the agrometeorological influences on the reproductive phase of plants, Mendoza et al. (2017)

Table 1. Recommended altitudes for growing guava.

\begin{tabular}{|c|c|c|}
\hline Altitude (m a.s.l.) & Annotation & Muthor \\
\hline $0-2,300$ & Ecuador & Solarte et al. (2014) \\
\hline $0-2,000$ & Grows in a wide range of altitudes & Hoyos (1989) \\
\hline $0-1,800$ & Venezuela & Natale et al. (2008) \\
\hline $0-1,700$ & This range favors the distribution & Paull and Duarte (2012) \\
\hline $0-1,500$ & In frost-free places & \\
\hline
\end{tabular}


found that rain is the climatic factor that most promotes this reproductive phase $(73.4 \%)$, when compared to temperature (19.3\%), followed by solar radiation or the photoperiod $(3.2 \%)$.

Salazar et al. (2006) reported that guava trees need a water supply of about 1,000 to 2,000 $\mathrm{m}^{3} \mathrm{ha}^{-1}$ year $^{-1}$, but Aguilera-Arango et al. (2020), in areas with a bimodal system, annual rainfall of 800 to $1,300 \mathrm{~mm}$ that is well-distributed, saw good development and production of the crop. On the other hand, Natale et al. (2008) stated that the ideal range of rainfall is 1,000 to $1,600 \mathrm{~mm}$, well-distributed throughout the year, but it should not be less than $600 \mathrm{~mm}_{\text {year }}{ }^{-1}$. In turn, because of the relative tolerance of guava to waterlogging (Crane et al., 2019), Hoyos (1989) reported that these plants can be grown in regions with rainfall between 1,000 and 3,000 $\mathrm{mm}$ per year; however, the same author reported that periods of excessive rains during the development of the fruit can cause cracking and harvest losses.

Excessive rains during fruit development make them more watery, with less firmness and reduced contents of sugars, titratable acidity and ascorbic acid. According to Souza et al. (2010), the values varied depending on the precipitation volumes and the ripening stages of the fruits. Menzel (1985) confirmed that excess water during the fruiting period increases the cracking and fall of fruits, similar to those of cape gooseberry (Fischer and Melgarejo, 2020). Sharma et al. (2020) reported that, in India, many crops in the summer rainy season are discarded because of poor commercial quality and found that bagging fruits with polypropylene non-woven bags is very beneficial for controlling pests and diseases and improving the harvest quality during the rainy season.

The favorable contribution of water in guava is not only essential for full vegetative growth but also in the beginning of the reproductive phase, in flowering, and in the setting and filling of fruits; therefore, in nature, flowering begins with the rainy season (Fischer et al., 2012; Paull and Duarte, 2012). The sprouting of the terminal branches that will carry the flowers requires an optimal supply of humidity (Mata and Rodríguez, 2000). These same authors reported that a minimum rainfall of 127 to $178 \mathrm{~mm}$ per month is required in Hawaii and that irrigation is applied to advance flowering, which also allows scheduling the harvest (Aguilera-Arango et al., 2020).

To replace the evaporated water in a guava plantation (25-50 mm/week), Nakasone and Paull (1998) suggested drip irrigation. In larger plantations that receive irrigation by sectors, they recommend sprinkler or microjet systems that, additionally, provide the nutrients quickly to the plant. Likewise, to guarantee the economic sustainability of a crop, Aguilar-Arango et al. (2020) suggested the application of irrigation, modification of the pruning season, and scheduling the main harvest taking into account the fact that pruned plant needs enough water for the development of new shoots.

Crane et al. (2019) classified the guava tree as tolerant to waterlogging, while Morton (1987) categorized it as moderately tolerant to waterlogging. Kongsri et al. (2020) observed that guava trees propagated by seedlings were more tolerant than those propagated by shoot layering under flooding conditions. Solarte et al. (2010) reported that prolonged rainfall can cause alterations in the normal production cycle in the Suarez river basin (Department of Santander, Colombia), which shorten harvest times. On the other hand, these authors observed an increase in the foliar anthocyanin pigments that decrease the photosynthetic capacity and thus the production of guava. In addition, very humid conditions increase diseases and pests (Singh, 2011), causing the abortion of a large number of fruits (Solarte et al., 2010). Likewise, environments with prolonged high relative humidity damage the quality of guavas (Fischer et al., 2012).

Taiwo et al. (2020) pointed out that drought is the most prevalent abiotic stress in the world, which limits the productivity of plantations. Therefore, in the dry tropics, the flowering of the guava is highly influenced by the availability of water (Paull and Duarte, 2012). Interestingly, guava is not only classified as tolerant to waterlogging but also moderately tolerant to droughts (Crane et al., 2019). Alix et al. (cited by Paull and Duarte, 2012) mentioned that this plant can withstand a dry period of about 6 months. This tolerance is surprising because of the superficial root system (Menzel, 1985). This tolerance is favored by the large number and extension of the roots that exceed the diameter of the crown (Bandera and Pérez, 2015). As previously mentioned, dry seasons combined with cold temperatures usually induce defoliation of the tree, which recovers fully if these conditions change (Nakasone and Paull, 1998). Furthermore, as Fischer et al. (2012) mentioned, low humid periods promote flower induction; while, on the contrary, dry conditions can induce the abortion of already formed flowers. 
Irrigation is necessary in regions with long dry seasons, which is why Paull and Duarte (2012) emphasized that the ideal pattern for guava is alternating conditions of dry and humid seasons since drought and low ambient humidity during flowering can seriously reduce fruit set and cause abscission of recently set fruit. Likewise, these authors stated that, when trees that suffer from water stress abort the fruits of $1-2 \mathrm{~cm}$ in diameter after intense irrigation or heavy rain, these trees resume vegetative growth. In addition, low humidity during fruit filling reduces size and causes a recollection of the pulp from the epidermis (Paull and Duarte, 2012).

As reported by Souza et al. (2010), the hydric conditions in guava promote optimum fruit quality, and excess water during fruit filling reduces the soluble solids content; while the sugar concentration is favored by water scarcity as a concentration effect (Mercado-Silva et al., 1998).

In drier environments, Solarte et al. (2014) found that, as the air vapor pressure deficit (DPV) and the maximum photonic flux density $\left(\mathrm{PPFD}_{\max }\right)$ increased, the concentrations of citric and succinic acid decreased in guava. The DPV and PPFD $_{\max }$ can influence the water status in fruits (Genard et al., 2009) and thus reduce the transpiration and photosynthesis rates of green fruits, affecting the primary metabolism of this organ.

\section{Salinity}

Jalil and Ansari (2020) reported that salinity occurs in areas with little rainfall and high temperatures, which promote high transpiration rates and affect the normal development of plants because of the use of saline water for irrigation, where excess sodium and chlorine ions cause toxicity and hinder the absorption of essential elements and water from the soil.

The guava tree shows moderate tolerance to salinity (Morton, 1987), and applications of calcium nitrate, $\mathrm{Ca}\left(\mathrm{NO}_{3}\right)_{2}$ of $10 \mathrm{mM}$, alleviatereductions in growth ofseedlings induced by $\mathrm{NaCl}$ through an increase in the concentration of foliar chlorophyll and higher photosynthetic rates (Ebert et al., 2002).

Many studies on salinity in guava were carried out in Brazil, especially in arid and semi-arid areas, where the scarcity of good quality water and the occurrence of low fertility soils are limiting factors in irrigated agriculture, which led to the use of salt water and nitrogen fertilizers as alternatives for agricultural production in these regions (Souza et al., 2017).

Salinity, especially at levels greater than $1.8 \mathrm{dS} \mathrm{m}^{-1}$, affects the emergence of seedlings, as well as growth and biomass accumulation in guava. The cultivar 'Crioula' is more tolerant to salinity than 'Paluma' and 'Ogawa' and is recommended as a rootstock (Sá et al., 2016). Cavalcante et al. (2005) found that four guava varieties with seedlings irrigated with an $\mathrm{EC}_{\mathrm{w}}$ greater than $1.5 \mathrm{dS} \mathrm{m}^{-1}, 180 \mathrm{~d}$ after sowing, did not have the agronomic quality for transplanting; while Ramírez et al. (2017) observed, in the germination, longitudinal root and stem growth of the variety 'Criolla Roja', a slight tolerance up to a concentration of $2.5 \mathrm{dS} \mathrm{m} \mathrm{m}^{-1}$ of $\mathrm{NaCl}$.Souza et al. (2020) found that $P$. cattleianum is not very suitable as a rootstock in saline areas because of its greater absorption of $\mathrm{Na}^{+}$, which leads to high levels of $\mathrm{Na}^{+}$in the leaves of the scion and, thus, lower tolerance to saline stress.

In the Paluma variety, increases in irrigation water salinity from $0.3 \mathrm{dS} \mathrm{m} \mathrm{m}^{-1}$ produced reductions in stomatal conductance, internal $\mathrm{CO}_{2}$ concentration, $\mathrm{CO}_{2}$ assimilation rate, transpiration, and efficiency in the instantaneous use of water, in addition to reducing the number of leaves and branches, the diameter of the stem and the absolute and relative growth rates (Bezerra et al., 2018a). However, in this study, the growth of 'Paluma' was affected by increases in the water salinity, and these plants could be irrigated with water of up to $1.42 \mathrm{dS} \mathrm{m}^{-1}$, causing an acceptable reduction of $10 \%$ in growth variables.

Cavalcante et al. (2010) managed to relieve the effects of salinity with the application of liquid bovine manure, but potassium applications failed to do so (Bonifácio et al., 2018). Applications of $\mathrm{N}$ above $70 \%$ of the recommended dose (378.7 $\mathrm{mg} \mathrm{N} \mathrm{dm}^{-3}$ soil) did not mitigate the detrimental effect of saline stress on plants (Bezerra et al., 2018b).

\section{Winds}

Paull and Duarte (2012) recommended windbreaks for guava, especially for high-quality dessert-type fruits produced for the fresh market. In addition, these authors reported that plants grafted on clonal rootstocks are very susceptible to wind speeds between 65 and $80 \mathrm{~km} \mathrm{~h}^{-1}$ during the first three years of cultivation; while trees exposed to winds between 16 and $32 \mathrm{~km} \mathrm{~h}^{-1}$ have branches that gradually develop out of the direction of the wind. 
On the contrary, Bandera and Pérez (2015) reported that, despite the fact that the root system of guava is superficial, it resists strong winds and storms thanks to the extension and number of large roots that exceed the width of the canopy of the crown, allowing this species to develop in a large number of different soils.

\section{CONCLUSIONS}

Guava, thanks to its ability to grow in tropical and subtropical climates, has been introduced to many low-latitude countries.

This crop grows in temperature ranges between 15 and $30^{\circ} \mathrm{C}$. Lower and higher temperatures reduce fruit set. Low temperatures make production difficult, causing flower drop or extending the fruit development phase. However, guava adapts well up to altitudes of 2,000 $\mathrm{m}$ a.s.l. Colombia has a high genotype $\times$ environment interaction in the production characteristics and fruit quality with respect to the elevation of the orchard.

An important ecophysiological factor in guava is water since crops require between 1,000 to 2,000 $\mathrm{mm}$ year ${ }^{-1}$ and endure waterlogging for several days; however, a lot of precipitation and environmental humidity decrease fruit quality considerably. On the other hand, since this tree is classified as moderately drought tolerant, this adversity greatly affects flowering and fruit set. In addition, since it has moderate tolerance to salinity, it supports irrigation water with up to an EC of 1.5 to $1.8 \mathrm{dS} \mathrm{m}^{-1}$ depending on the variety.

Guava should be researched under conditions of elevated $\mathrm{CO}_{2}$ concentrations, along with interactions with nitrogen fertilization.

Conflict of interests: The manuscript was prepared and reviewed with the participation of the authors, who declare that there exists no conflict of interest that puts at risk the validity of the presented results.

\section{BIBLIOGRAPHIC REFERENCES}

Agronet. 2020. Guayaba. In: https://www.agronet.gov. co/estadistica/Paginas/home.aspx?.cod $=1$; consulted: November, 2020.

Aguilera-Arango, G.A., E. Rodríguez-Henao, H.N. Chaparro-Zambrano, and J.O. Orduz-Rodríguez. 2020.
Estado actual de la investigación para el cultivo de guayaba en Colombia. Agron. Mesoamer. 31(3), 845860. Doi: $10.15517 /$ am.v31i3.40207

Arteaga, L. and J. Burbano. 2018. Efectos del cambio climático: Una mirada al Campo. Rev. Cienc. Agríc. 35(2), 79-91. Doi: 10.22267/rcia.183502.93

Bandera, E. and L. Pérez. 2015. Mejoramiento genético de guayabo (Psidium guajava L.). Cult. Trop. 36(Sp. Tiss.), 96-110.

Bezerra, I.L., R.G. Nobre, H.R. Gheyi, G.S. Lima, and J.L. Barbosa. 2018a. Physiological indices and growth of 'Paluma' guava under saline water irrigation and nitrogen fertigation. Rev. Caatinga 31(4), 808-816. Doi: 10.1590/1983-21252018v31n402rc

Bezerra, I.L., R.G. Nobre, H.R. Gheyi, L.P. Souza, F.W.A. Pinheiro, and G.S. Lima. 2018b. Morphophysiology of guava under saline water irrigation and nitrogen fertilization. Rev. Bras. Eng. Agríc. Ambient. 22(1), 32-37. Doi: 10.1590/1807-1929/agriambi.v22n1p32-37

Blancke, R. 2016. Tropical fruits and other edible plants of the world. Cornell University Press, Ithaca and London. Doi: 10.7591/9781501704284

Bonifácio, B.F., R.G. Nobre, A.S. Sousa, E.M. Gomes, E.M. Silva, and L.P. Sousa. 2018. Efeitos da adubação potássica e irrigação com águas salinas no crescimento de porta-enxerto de goiabeira. Rev. Ciênc. Agr. 41(4), 971-980. Doi: 10.19084/RCA18119

Campos, D., R. Chirinos, L. Gálvez, and R. Pedreschi. 2018. Bioactive potential of Andean fruits, seeds, and tubers. pp. 287-343. In: Toldra, F. (ed.). Advances in food and nutrition research. Vol. 84. Elsevier, Cambridge, MA. Doi: 10.1016/bs.afnr.2017.12.005

Cavalcante, L.F., Í.H.L Cavalcante, K.S.N. Pereira, F.A. Oliveira, S.C Gondim, and F.A.R. Araújo. 2005. Germination and initial growth of guava plants irrigated with saline wáter. Rev. Bras. Eng. Agríc. Ambient. 9(4), 515519. Doi: 10.1590/S1415-43662005000400012

Cavalcante, L.F., M.S. Vieira, A.F. Santos, W.M. Oliveira, and J.A.M. Nascimento. 2010. Água salina e esterco bovino líquido na formação de mudas de goiabeira cultivar Paluma. Rev. Bras. Frutic. 32(1), 251-261. Doi: 10.1590/S0100-29452010005000037

Crane, J.H., C.F. Balerdi, and B. Schaffer. 2019. Managing your tropical fruit grove under changing water table levels. Doc. HS957. Horticultural Sciences Department, UF/IFAS Extension, Gainesville, FL.

DaMatta, F.M., A. Grandis, B.C. Arenque, and M.S. Buckeridge. 2010. Impacts of climate changes on crop physiology and food quality. Food Res. Int. 43, 1814-1823. Doi: 10.1016/j.foodres.2009.11.001

Devenish, C. and C. Gianella (eds.). 2012. 20 years of sustainable mountain development in the Andes -from Rio 1992 to 2012 and beyond-. Consorcio para el 
Desarrollo Sostenible de la Ecorregión Andina, CONDESAN, Lima.

Ebert, G., J. Eberle, H. Ali-Dinar, and P. Lüdders. 2002. Ameliorating effects of $\mathrm{Ca}\left(\mathrm{NO}_{3}\right)_{2}$ on growth, mineral uptake and photosynthesis of $\mathrm{NaCl}$-stressed guava seedlings (Psidium guajava L.). Sci. Hortic. 93, 125-135. Doi: 10.1016/S0304-4238(01)00325-9

Farias, D.P., I.A. Neri-Numa, F.F. Araújo, and G.M. Pastore. 2020. A critical review of some fruit trees from the Myrtaceae family as promising sources for food applications with functional claims. Food Chem. 306, 125630. Doi: 10.1016/j.foodchem.2019.125630

Ferreira, M.C., F.B. Martins, G.W.L. Florêncio, and L.A.A.P. Pasin. 2019. Cardinal temperatures and modeling of vegetative development in guava. Rev. Bras. Eng. Agríc. Ambient. 23(11), 819-825. Doi: 10.1590/18071929/agriambi.v23n11p819-825

Fischer, G. and L.M. Melgarejo. 2020. The ecophysiology of cape gooseberry (Physalis peruviana L.) - an Andean fruit crop. A review. Rev. Colomb. Cienc. Hortic. 14(1), 76-89. Doi: 10.17584/rcch.2020v14i1.10893

Fischer, G., L.M. Melgarejo, and D. Miranda. 2012. Guayaba (Psidium guajava L.). pp. 526-549. In: Fischer, G. (ed.). Manual para el cultivo de frutales en el trópico. Produmedios, Bogota.

Fischer, G. and J.O. Orduz-Rodríguez. 2012. Ecofisiología en los frutales. pp. 54-72. In: Fischer G. (ed.). Manual para el cultivo de frutales en el trópico. Produmedios, Bogota.

Fischer, G. and A. Parra-Coronado. 2020. Influence of environmental factors on the feijoa (Acca sellowiana [Berg] Burret) crop. A review. Agron. Colomb. 38(3). Doi: 10.15446/agroncolomb.v38n3.88982

Fischer, G., F. Ramírez, and F. Casierra-Posada. 2016. Ecophysiological aspects of fruit crops in the era of climate change. A review. Agron. Colomb. 34(2), 190-199. Doi: 10.15446/agron.colomb.v34n2.56799

Genard, M., C. Gibert, C. Bruchou, and F. Lescourret. 2009. An intelligent virtual fruit model focusing on quality attributes. J. Hort. Sci. Biotech. ISAFRUIT Suppl. 84(6), 157-163. Doi: 10.1080/14620316.2009.11512614

Gómez, G. and N. Rebolledo-Podleski. 2006. Módulo del cultivo de la Guayaba. Corporación Colombiana de Investigación Agropecuaria (Corpoica), Mosquera, Colombia.

Haokip, S.W., K. Shankar, and J. Lalrinngheta 2020. Climate change and its impact on fruit crops. J. Pharmacog. Phytochem. 9(1), 435-438.

Hoyos, J. 1989. Frutales en Venezuela. Sociedad de Ciencias Naturales La Salle, Caracas.

Insuasty, O., R. Monroy, A.D. Fonseca, and J. Bautista. 2007. Manejo integrado del picudo de la guayaba (Conotrachelus psidii Marshall) en Santander. Produmedios, Bogota.
Jalil, S.U. and M.I. Ansari. 2020. Stress implications and crop productivity. pp. 73-86. In: Hasanuzzaman, M. (ed.). Plant ecophysiology and adaption under climate change: Mechanisms and perspectives I. Springer Nature, Singapore. Doi: 10.1007/978-981-15-2156-0_3

Kongsri, S., P. Nartvaranant, and U. Boonprakob. 2020. A comparison of flooding tolerance of guava tree propagated from shoot layering and seedling. Acta Hortic. 1298, 625-632.Doi: 10.17660/ActaHortic.2020.1298.86

Lambers, H., F.S. Chapin III, F. Stuart, and T.L. Pons. 2008. Plant physiological ecology. Springer, New York. Doi: 10.1007/978-0-387-78341-3

Ligarreto, G. 2012. Recursos genéticos de especies frutícolas en Colombia. pp. 35-53. In: Fischer, G. (ed.). Manual para el cultivo de frutales en trópico. Produmedios, Bogota.

López-Santos, J., T. Castañeda-Martínez, and J.G. González-Díaz. 2017. Nueva ruralidad y dinámicas de proximidad en el desarrollo territorial de los sistemas agroalimentarios localizados. Polis 47, 211-233. Doi: 10.4067/S0718-65682017000200211

Marengo, J.A., J.D. Pabón, A. Díaz, G. Rosas, G. Ávalos, E. Montealegre, M. Villacis, S. Solman, and M. Rojas. 2011. Climate change: evidence and future scenarios for the Andean region. pp. 110-127. In: Herzog, S., R. Martinez, P.M. Jorgensen, and H. Tiessen (eds.). Climate change and biodiversity in the tropical Andes. IAI; SCOPE; UNESCO, Paris.

Mata, I. and A. Rodríguez. 2000. Cultivo y producción de guayaba. Trillas, Mexico, DF.

Mendoza, M., C.A. Peres, and L.P.C. Morellato. 2017. Continental-scale patterns and climatic drivers of fruiting phenology: A quantitative Neotropical review. Glob. Planet. Change 148, 227-241. Doi: 10.1016/j. gloplacha.2016.12.001

Menzel, C.M. 1985. Guava: An exotic fruit with potential in Queensland. Queensl. Agric. J. 111(2), 93-98.

Mercado-Silva, E., P. Benito-Bautista, and M.A. Garcia-Velasco. 1998. Fruit development, harvest index and ripening changes of guavas produced in Central México. Postharvest Biol. Technol. 13, 143-150. Doi: 10.1016/ S0925-5214(98)00003-9

Methela, N.J., O. Faruk, M.S. Islam, and M.M. Hossain. 2019. Morphological characterization of guava germplasm (Psidium sp.). J. Biosci. Agric. Res. 20(01), 16711680. Doi: 10.18801/jbar.200119.203

Mittler, R. 2006. Abiotic stress, the field environment and stress combination. Trends Plant Sci. 11, 15-19. Doi: 10.1016/j.tplants.2005.11.002

Mishra, M., S.U. Jalil, N. Sharma, and U. Hudedamani. 2014. An Agrobacterium mediated transformation system of guava (Psidium guajava L.) with endochitinase gene. Crop Breed. Appl. Biotechnol. 14, 232-237. Doi: 10.1590/1984-70332014v14n4a36 
Moreno-Miranda, C., R. Moreno-Miranda, A.A. Pilamala-Rosales, and J.I. Molina-Sánchez. 2019. El sector hortofrutícola de Ecuador: Principales características socio-productivas de la red agroalimentaria de la uvilla (Physalis peruviana). Cienc. Agric. 16(1), 31-55. Doi: 10.19053/01228420.v16.n1.2019.8809

Moreno, E., B.L. Ortiz, and L.P. Restrepo. 2014. Contenido total de fenoles y actividad antioxidante de pulpa de seis frutas tropicales. Rev. Colomb. Quím. 43(3), 4148. Doi: 10.15446/rev.colomb.quim.v43n3.53615

Morton, J.F. 1987. Fruits of warm climates. Julia F. Morton, Miami, FL.

Musyarofah, N., S. Susanto, S.A. Aziz, K. Suket, and Dadang. 2020. The diversity of 'kristal' guava (Psidium guajava) fruit quality in response to different altitudes and cultural practices. Biodiversitas 21, 3310-3316. Doi: $10.13057 /$ biodiv/d210755

Nakasone, H.Y. and R.E. Paull. 1998. Tropical fruits. CAB International, Wallingford, UK.

Natale, W., R.M. Prado, J.A. Quaggio, and D. Mattos Jr. 2008. Guava. In: Crisóstomo, L., A. Nuamov, and A.E. Johnston (eds.). Fertilizing for high yield and quality tropical fruits of Brazil. International Potash Institute Bulletin, Horgen, Switzerland.

Parra-Coronado, A. 2014. Maduración y comportamiento poscosecha de la guayaba (Psidium guajava L.). Una revisión. Rev. Colomb. Cienc. Hortic. 8(2), 314-327. Doi: 10.17584/rcch.2014v8i2.3223

Paull, R.E. and O. Duarte. 2012. Tropical fruits. Vol. 2. $2^{\text {nd }}$ ed. CABI International, Wallingford, UK. Doi: 10.1079/9781845937898.0000

Pérez, L.V. and L.M. Melgarejo. 2015. Photosynthetic performance and leaf water potential of gulupa (Passiflora edulis Sims, Passifloraceae) in the reproductive phase in three locations in the Colombian Andes. Acta Biol. Colomb. 20(1), 183-194. Doi: 10.15446/abc. v20n1.42196

Pérez-Gutiérrez, R.M.P., S. Mitchell, and R.V. Solis. 2008. Psidium guajava: A review of its traditional uses, phytochemistry and pharmacology. J. Ethnopharm. 117(1), 1-27. Doi: 10.1016/j.jep.2008.01.025

Prado, R.M., J.P.S. Junior, G.P.S. Júnior, and I.H.L Cavalcante. 2017. Guava: The relationship between the productive aspects, the quality of the fruits and its health benefits. pp. 1-16. In: Murphy, A. (ed.). Guava: Cultivation, antioxidant properties \& health benefits. Nova Science Publishers, New York, NY.

Rai, M.K. and U. Jaiswal. 2020. Psidium guajava Guava. pp. 330-342. In: Litz, R.E., F. Pliego-Alfaro, and J.I. Homaza. (eds.). Biotechnology of fruit and nut crops. $2^{\text {nd }} e d$. CAB International, Wallingford, UK. Doi: 10.1079/9781780648279.0330

Ramadan, M.F. 2011. Bioactive phytochemicals, nutritional value, and functional properties of cape gooseberry
(Physalis peruviana): An overview. Food Res. Int. 44, 1830-1836. Doi: 10.1016/j.foodres.2010.12.042

Ramírez, F. and J. Kallarackal. 2018. Climate change, tree pollination and conservation in the tropics: a research agenda beyond IPBES. Wiley Interdiscip. Rev. Clim. Change 9(1), e502. Doi: 10.1002/wcc.502

Ramírez, M., A. Urdaneta, and E. Pérez. 2017. Germinación del guayabo tipo 'Criolla Roja' bajo condiciones de salinidad por cloruro de sodio. Bioagro 29(1), 65-72.

Raza, A., F. Ashraf, X. Zou, X. Zjang, and H. Tosif. 2020. Plant adaptation and tolerance to environmental stresses: Mechanisms and perspectives. pp. 117146. In: Hasanuzzaman, M. (ed.). Ecophysiology and adaptation under climate change: mechanisms and perspectives I. Springer Nature Singapore. Doi: 10.1007/978-981-15-2156-0_5

Restrepo-Díaz, H. and A.D. Sánchez-Reinoso. 2020. Ecophysiology of fruit crops: A glance at its impact on fruit crop productivity. pp. 59-66. In: Srivastava, A.K. and C. $\mathrm{Hu}$ (eds.). Fruit crops: Diagnosis and management of nutrient constraints. Elsevier. Doi: 10.1016/ B978-0-12-818732-6.00005-8

Sá, F.W.S., R.G. Nobre, L.A. Silva, R.C.L. Moreira, E.P Paiva, and F.A. Oliveira. 2016. Tolerance of guava rootstocks under salt stress. Rev. Bras. Eng. Agríc. Ambient. 20(12), 1072-1077. Doi: 10.1590/1807-1929/agriambi. v20n12p1072-1077

Salazar, D.M., P. Melgarejo, R. Martínez, J.J. Martínez, F. Hernández, and M. Burguera. 2006. Phenological stages of the guava tree (Psidium guajava L.). Sci. Hortic. 108, 157-161. Doi: 10.1016/j.scienta.2006.01.022

Sánchez-Reinoso, A.D., Y. Jiménez-Pulido, J.P. Martínez-Pérez, C.S. Pinilla, and G. Fischer. 2019. Parámetros de fluorescencia de la clorofila y otros parámetros fisiológicos como indicadores del estrés por anegamiento y sombrío en plántulas de lulo (Solanum quitoense var. septentrionale). Rev. Colomb. Cienc. Hortic. 13(3), 325335. Doi: 10.17584/rcch.2019v13i3.10017

Sentelhas, P.C., C.T.P Junior, J.M.M. Sogristi, R. Kavati, and M.T. Parodi. 1996. Temperatura letal de diferentes plantas frutíferas tropicais. Bragantia 55(2), 231-235. Doi: 10.1590/S0006-87051996000200004

Sharma, R.R., A. Nagaraja, A.K. Goswami, M. Thakre, and E. Varghese. 2020. Influence of on-the-tree fruit bagging on biotic stresses and postharvest quality of rainy-season crop of 'Allahabad Safeda' guava (Psidium guajava L.). Crop Prot. 135, 105216. Doi: 10.1016/j. cropro.2020.105216

Shukla, P.R., J. Skea, R. Slade, R. Van Diemen, E. Haughey, J. Malley, M. Pathak, and J. Portugal Pereira (eds.). 2019. Technical summary, 2019. In: Climate change and land: an IPCC special report on climate change, desertification, land degradation, sustainable land management, food security, and greenhouse gas fluxes 
in terrestrial ecosystems, https://www.ipcc.ch/site/ assets/uploads/sites/4/2019/11/03_Technical-Summary-TS.pdf; consulted: August, $202 \overline{0}$.

Singh, G. 2007. Recent development in production of guava. Acta Hortic. 735, 161-176. Doi: 10.17660/ ActaHortic.2007.735.21

Singh, S.P. 2011. Guava (Psidium guajava L.). pp. 213-246. In: Yahia, E.M. (ed.). Postharvest biology and technology of tropical and subtropical fruits. Vol 3. Cocona to mango. Woodhead Publishing, Oxford, UK. Doi: 10.1533/9780857092885.213

Singh, G., H. Sahare, and M. Deep. 2019. Recent trends in guava propagation - A review. Biosci. Biotechnol. Res. Asia 16(1), 143-154. Doi: 10.13005/bbra/2732

Solarte, M.E., L.M. Melgarejo, O. Martínez, M.S. Hernández, and J.P. Fernández-Trujillo. 2014. Fruit quality during ripening of Colombian guava (Psidium guajava L.) grown at different altitudes. J. Food Agric. Environ. 12(2), 669-675.

Solarte, M.E., H.M. Romero, and L.M. Melgarejo. 2010. Caracterización ecofisiológica de la guayaba de la Hoya del Río Suárez. pp. 25-56. In: Melgarejo, L.M. and A.L. Morales (eds.). Desarrollo de productos funcionales promisorios a partir de la guayaba (Psidium guajava L.) para el fortalecimiento de la cadena productiva. Universidad Nacional de Colombia, Bogota.

Souza, A.G., C.S. Marinho, M.P.S. Silva, W.S.G. Carvalho, G.S. Campos, and B.A. Pestana. 2020. Guava seedlings with rootstocks or interstocks and their reaction to salinity. Bragantia 79(1), 74-82. Doi: 10.1590/1678-4499.20190210

Souza, P.M.B. and F.B. Martins. 2014. Estimativa da temperatura basal inferior para as cultivares de oliveira
Grappolo e Maria da Fé. Rev. Bras. Meteor. 29, $307-$ 313. Doi: 10.1590/S0102-77862014000200013

Souza, L.P., R.G. Nobre, E.M. Silva, H.R. Ghey, and L.A.A. Soares. 2017. Produção de porta-enxerto de goiabeira cultivado com águas de diferentes salinidades e doses de nitrogênio. Rev. Ciênc. Agron. 48(4), 596-604. Doi: 10.5935/1806-6690.20170069

Souza, M.E., A.C. Silva, A.P. Souza, A.A. Tanaka, and S. Leonel. 2010. Influência das precipitações pluviométricas em atributos físico-químicos de frutos da goiabeira 'Paluma' em diferentes estádios de maturação. Rev. Bras. Frutic. 32(2), 637-646. Doi: 10.1590/ S0100-29452010005000060

Taiwo, A.F., O. Daramola, M. Sow, and V.K. Semwal. 2020. Ecophysiology and responses of plants under drought. In: Hasanuzzaman, M. (ed.). Plant ecophysiology and adaptation under climate change: Mechanisms and perspectives I. Springer Nature Singapore. Doi: 10.1007/978-981-15-2156-0_8

Thaipong, K. and U. Boonprakob. 2005. Genetic and environmental variance components in guava fruit qualities Sci. Hortic. 104, 37-47. Doi: 10.1016/j. scienta.2004.07.008

Tito, R., H.L. Vasconcelos, and K.J. Feeley. 2018. Global climate change increases risk of crop yield losses and food insecurity in the tropical Andes. Glob. Change Biol. 24(2), 592-6011. Doi: 10.1111/gcb.13959

Viera, W., A. Sotomayor, and P. Viteri. 2019. Breeding of three Andean fruit crops in Ecuador. Chron. Hortic. 59(4), 20-29.

Yadava, U.L. 1996. Guava: An exotic tree fruit with potential in the Southeastern United States. HortScience 31(5), 789-794. Doi: 10.21273/HORTSCI.31.5.789 